\title{
Improvement of dry tropical rangelands in Hai- nan Island, China: 1. Evaluation of pasture legumes
}

\author{
DAVID L. MICHALK, FU NAN-PING, AND ZHU CHIN-MING
}

Authors are former director, former pasture technician, and production manager of Gaopoling Model Cattle Farm, Ba Suo, Dong Fang County, Hainan Island, People's Republic of China.

\begin{abstract}
During 1981-83, we studied some legumes for potential improvement of dry tropical $(1,001 \mathrm{~mm}$ annual rainfall) rangelands in Hainan Island, China. The productivity and persistence of 16 pasture legumes were tested on sandy $(<5 \mathrm{mg} / \mathrm{kg}$ available $P$ ) and loam $(12-25 \mathrm{mg} / \mathrm{kg})$ soils under cutting in a randomized block design with plots split for sequential sowings in 1981, 1982, and 1983. Dry matter yield, sward composition, and legume density were measured at the end of the wet and dry seasons each year. Thirteen legumes established with density averaged over 3 sequential sowings $>1 \mathrm{plant} / \mathrm{m}^{2}$ on 1 or both soils, but only 5 perennial stylos (Stylosanthes), siratro [Macroptilium atropurpureum (D.C.) Urban], and centro (Centrosema pubescens Benth) (loam soil only) persisted through 2 dry seasons and yielded more than 0.5 metric tonne (t)/ha in 3-year-old swards. S. guianensis (Aubl.) Sw. cv Cook yielded best on both soils, but proved less tolerant to fire than cv Graham, which is the common stylo recommended by this study as a companion for siratro for improvement of loam soil rangeland. Siratro was the only non-stylo to produce $>2 t /$ ha and show relative stability with sward age, but careful grazing management and regular fertilization are needed to maintain siratro content above $40 \%$ in commercial sowings. Tolerance to fire, low $P$ requirement, and high yield in 2-and 3-year-old stands makes $S$. scabra Vog. cv Seca the most suitable legume for sandy soil, but since it is slow to establish, a mixture of $S$. scabra and $S$. hamata (L.) Taub.cv Verano which is noted for its quick establishment and prolific seed production is recommended for range improvement of low $P$ soils.
\end{abstract}

Key Words: China, dry tropical, legumes, Stylosanthes, superphosphate, anthracnose, fire tolerance

China has implemented a national program to rapidly increase the output of red meat from rangelands (Zhao 1981). Agricultural planners in the southern provinces of Guangdong and Hainan identified the dry tropics of western Hainan (Fig. 1) as a region suitable for range improvement on 2 counts: (1) unlike other parts of the island, the potential to boost agricultural income through increased production of food, field, and plantation crops is limited by low rainfall and poor soils; and (2) this region which covers $20 \%$

\footnotetext{
The authors wish to thank Huang Zhen-Sheng, former manager of Gaopoling Farm, for providing facilities for the experimental program and the Pasture Production Team for assisting with the field work. The vital communication link provided by interpreters Deng Zhou-Lien and Yen Ren-Chang between Australian advisers and their Chinese counterparts is gratefully acknowledged. DLM also thanks other members of the Australian team at Gaopoling Farm, Dr. J.F. Ayres and Mr. S.E. Dunn and NSW Agriculture Overseas project Director, Mr. G.D. Slennett, for their support and encouragement. The work was conducted under the auspices of the in areement. The statistical advice provided by AII I

Manuscript accepted 8 Nov. 1992.
}

of Hainan already has an abundance of native (Huang Niu) cattle numbering 70,000 or $25 \%$ of Hainan's herd and a large area of rangeland with potential for cattle production.

To increase beef production from these dry tropical rangelands, cattle nutrition must be improved. During the late wet season and protracted dry season, the nutritive value of native vegetation severely limits productivity of beef cattle. Studies on Yellow Ox cattle in south China show that low calving percentages, high mortality of lactating cows, and low turnoff rates of inferior quality animals are directly related to protein deficiency in native pasture (Ayres et al. 1983).

Based on studies in Australia and South America, livestock nutrition can best be improved by broadcasting legumes into grassdominated rangelands to increase the quantity and quality of available forage (Hutton 1979, Walker 1983). For many years, Stylosanthes humilis H.B.K. (Townsville stylo) and superphosphate was the standard recommendation for improvement of native grassland throughout northern Australia (Humphreys 1967), and in monsoonal areas of south-east Asia, Latin America, and East Africa (Kretschmer 1965). However, because of its susceptibility to anthracnose (Colletotrichum gloeosporioides Penz.) fungus (Irwin and Cameron 1978), S. hamata (L.) Taub and S. scabra Vog. are not recommended as replacements for $S$. humilis in the dry tropics (Gillard et al. 1980), while S. guianesis (Aubl.) Sw. has proved to be more productive in areas where annual rainfall exceeds $1,000 \mathrm{~mm}$ (Bishop et al. 1981).

In addition to the Stylosanthes species, Macroptilium atropurpureum (DC.) Urban (Siratro) is a persistent and productive trailing legume adapted to a wide range of soil and vegetation types with annual rainfall as low as $750 \mathrm{~mm}$ ('t Mannetje 1974) including the dry tropics (Anning 1982b). Centrosema pubescens Benth., although more suited to the wet tropics (Hutton 1970), will persist in $1,100 \mathrm{~mm}$ rainfall areas when grown on clay soils with favourable moisture regimes (Anning 1982b).

While agricultural planners in Guangdong Province were aware of the value of these legumes for improving cattle production, they also recognized that a lack of local expertise in range science posed a serious limitation to progress in Hainan Island. Assistance was sought from New South Wales, Guangdong's sister state in Australia (Saville and Sheridan 1980), to develop a joint range improvement program with the following objectives: (1) to select forage species adapted to dry tropical Hainan; (2) to determine fertilizer requirements of different forage species; and (3) to develop methods of establishment and utilization (Michalk and Dunn 1984). Finance for the program was provided by Guangdong, and technical input by New South Wales. In this paper of a series focusing on range improvement in the dry tropics of China, we 


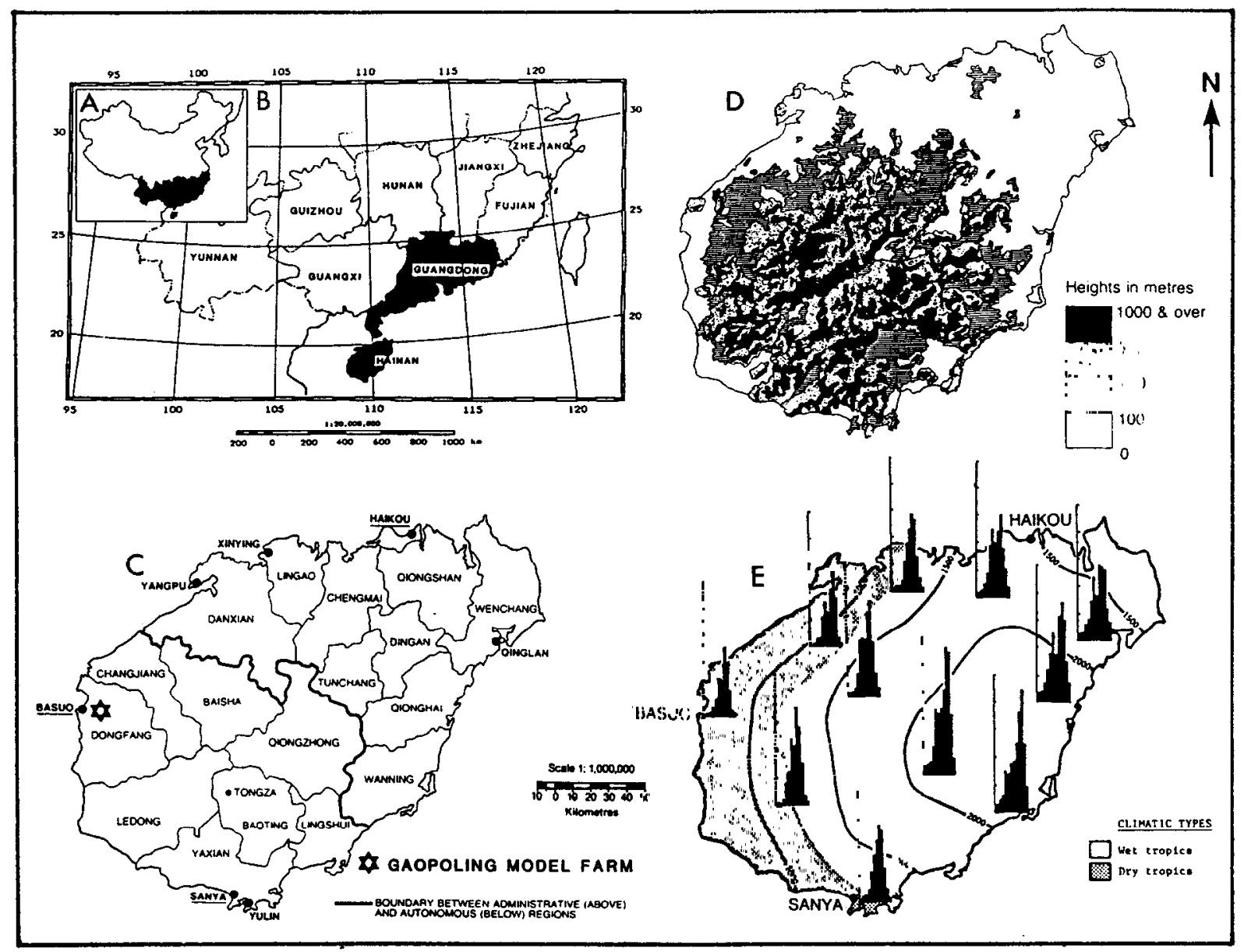

Fig. 1. (a) Location of China's tropical and subtropical region; (b) location of Guangdong and Hainan; (c) counties of Hainan and location of Gaopoling Model Cattle Farm; (d) topography of Hainan; and (e) dry tropical region delineated by rainfall isohyets.

report on our studies conducted between 1981 and 1983 at Gaopoling Model Cattle Farm which aimed to select pasture legumes that would: (1) grow and produce seed on sandy soil under phosphorus and water stresses; (2) persist under grazing; and (3) tolerate pests and diseases. No evaluation of pasture legumes had been undertaken in the dry tropics of Hainan prior to the reported studies.

\section{Location and Environment of Hainan's Dry Tropical Range- lands}

\section{Location}

Hainan Island, which lies between longitudes $108^{\circ} 30^{\prime}$ and $111^{\circ}$ E, and latitudes $18^{\circ}$ and $20^{\circ} 31 \mathrm{~N}$ (Fig. 1), forms the extreme southern limit of the People's Republic of China, except for the disputed Paracel Reefs. With an area of $34,077 \mathrm{~km}^{2}$ (Anon. 1982), the oval-shaped island ranks as the world's 26th largest island. Although it accounts for less than $1 \%$ of China's land area, its tropical climate, rich mineral and petroleum resources (Anon. 1982), and strategic location make Hainan an important, yet undeveloped, region of China (Michalk 1986).

Gaopoling Model Cattle Farm $\left(19^{\circ} 09 \mathrm{~N} ; 108^{\circ} 68^{\prime} \mathrm{W}\right)$ is $14 \mathrm{~km}$ west of Ba Suo township on 2,000 ha of undulating coastal plain in Dong Fang County, Hainan Island (Fig. 1). This large area was chosen because Guangdong officials believed that demonstration of range improvement on a large, rather than on a small scale would serve as a better model for extension of the program to other state farms. The model farm is typical of dry tropical rangeland found in western Hainan where annual rainfall averages less than $1,400 \mathrm{~mm}$ (Fig. 1). It is representative of the 162,000 ha set aside by the Hainan government for range improvement.

\section{Climate}

Lying in a rain-shadow cast by the Five-Finger and Red Mist Mountain Ranges (Fig. 1), Dong Fang county has a seasonally dry savanna-type climate with an average annual rainfall of $1,001 \mathrm{~mm}$ (Table 1), $85 \%$ of which falls during the 5-month wet season (mid-May to mid-October). Table 1 also shows the monthly rainfall recorded at Gaopoling Farm over the experimental period (1981-1983).

Year-to-year variability in rainfall is large with annual totals over the last 29 years (1955-83) ranging from $275 \mathrm{~mm}$ in 1969 to a maximum of 1,529 in 1980 . The probability of a drought year occurring in Dong Fang county is 1 year in 7 . Drought years occur when the anticyclone over Mongolia persists into late May or June, which delays the onset of the typhoon season, or when local synoptic patterns are such that typhoons curve towards Japan without entering the South China Sea.

Typhoons make a significant contribution to rainfall in western Hainan. Records from the Dong Fang County Weather Station show that over the $1955-83$ period $46 \%$ of the annual total was associated with typhoons, two-thirds of which occurred in the July to September period. During the experimental period between 3 and 8 typhoons were recorded, accounting for 42 to $64 \%$ of total rainfall (Table 1). Typhoon rain occurs as intense, short duration storms with $417 \mathrm{~mm}$ (July 1983) being the highest fall recorded in a single day in Dong Fang County.

Mean monthly maximum/minimum temperatures for the experimental period ranged from $23 / 15^{\circ} \mathrm{C}$ in January to $32 / 26^{\circ} \mathrm{C}$ in 
Table 1. Average climatic parameters for Dong Fang County (1955 to 1981) and Gaopoling Farm rainfall for 1981-1983.

\begin{tabular}{|c|c|c|c|c|c|c|c|}
\hline & \multicolumn{4}{|c|}{ Rainfall } & \multirow[b]{2}{*}{ Evaporation } & \multirow{2}{*}{$\begin{array}{c}\text { Average } \\
\text { temperature }\end{array}$} & \multirow[b]{2}{*}{ Solar radiatior } \\
\hline & Mean & 1981 & 1982 & 1983 & & & \\
\hline & $\ldots$ & $\ldots$ & $\ldots$ & $\ldots$ & $(\mathrm{mm})$ & $\left({ }^{\circ} \mathrm{C}\right)$ & (cal/ $\mathrm{cm}^{2}$ day) \\
\hline January & 7 & 3 & 0 & 17 & 127 & 19.2 & 258 \\
\hline February & 13 & 2 & 33 & 5 & 109 & 19.9 & 286 \\
\hline March & 17 & 0 & 1 & 101 & 140 & 22.9 & 323 \\
\hline April & 32 & 63 & 25 & I1 & 185 & 26.0 & 400 \\
\hline May & 63 & 30 & 147 & 33 & 247 & 28.9 & 468 \\
\hline June & 143 & 143 & 195 & 77 & 224 & 28.9 & 467 \\
\hline July & 138 & 128 & 126 & 565 & 234 & 29.4 & 484 \\
\hline August & 254 & 181 & 33 & 244 & 186 & 29.2 & 419 \\
\hline September & 203 & 57 & 190 & 64 & 148 & 28.6 & 367 \\
\hline October & 101 & 200 & 199 & 141 & 157 & 27.6 & 355 \\
\hline November & 22 & 20 & 128 & $\mathbf{0}$ & 146 & 23.0 & 333 \\
\hline December & 8 & 0 & 8 & 8 & 136 & 20.5 & 258 \\
\hline Total & 1001 & 827 & 1085 & 1266 & & & \\
\hline Number of typhoons & 5 & 6 & 8 & 3 & & & \\
\hline$\%$ total rain & 46 & 42 & 50 & 64 & & & \\
\hline
\end{tabular}

July, similar to the long-term temperature regime for the county (Table 1). Dong Fang has the hottest summer recorded in Hainan, even though the hottest maximum temperature ever recorded in the county is only $35.4^{\circ} \mathrm{C}$. During the study period, the highest temperature $\left(35^{\circ} \mathrm{C}\right)$ was recorded on 13 May 1983 , while minimum temperature did not fall below $9^{\circ} \mathrm{C}$.

\section{Soils}

Rangeland soils of Hainan's dry tropics are mapped as "dry red earth" in the Chinese classification system, which equates with Usttorroxs in Soil Taxonomy (Zhao and Shi 1986). Soil texture ranges from deep siliceous sands on the coastal plain to red loam in the undulating hinterland (Xiong and Tang 1986). The phosphorus infertile ( $<5 \mathrm{mg} / \mathrm{kg}$ available $P$ ) sandy soil (Table 2 ) covers $60 \%$ of the area of Gaopling Farm (Michalk and Dunn 1984) interspersed with small areas of moderately fertile red loam (Table 2) which is more typical of the "dry red earths" described by Zhao and Shi (1986).

\section{Unimproved Rangeland Vegetation}

Vegetation ranges from monsoonal scrub with tall bunchgrasses from the genera Heteropogon, Dichanthium, Chrysopogon, and Themeda forming the understory on better loam soil to degraded grassland dominated by blady grass (Imperata cylindrica (L.) Beauv. var. major (Nees.) C.E. Hubbard) and prostrate, grazingtolerant grasses on sandy soil. Scrub species on the coastal plain include: Grewia spp. (14\%); Helicteres spp. (11\%); Aglaia dasyclada How \& T.C. Chen (5\%); Quercus helferana (Yu) L. Menitski (4\%); and a number of shrubby Desmodiums.
Forage production ranges from $1.1 \mathrm{t} /$ ha on degraded grassland to $2.2 t /$ ha on low density ( $<5,000$ shrubs / ha) scrubland (Michalk and $\mathrm{Fu} 1988$ ). Native legumes, mostly from the genera Desmodium and Alysicarpus, which account for less than $10 \%$ of total herbaceous biomass on unimproved rangeland, are not very responsive to superphosphate (Michalk and Fu 1988).

\section{Materials and Methods}

To select suitable legumes, 16 species/cultivars which included types with erect and trailing growth form (Table 3) were chosen for study based on their performance in Australia. Legumes were sown at recommended seeding rates (Table 3 ) into weed-free, cultivated seedbeds in sequential plantings in 1981 (1 August), 1982 (15 June), and 1983 (12 July) on sandy and red loam soils. Study subplots were $21 \mathrm{~m}^{2}(3 \mathrm{~m} \times 7 \mathrm{~m})$ and replicated 3 times. Legume seed was scarified using hot water treatment, inoculated with commercial Rhizobia in peat, and pelleted with rock phosphate or lime prior to planting.

A newly cleared red loam site was stick-raked and ploughed between April and planting for the 1981 sowing, but old cultivation areas were used for the 1982 and 1983 sowings. Heavily grazed sites were selected for sandy soil studies. All plots were fertilized with local Grade 4 superphosphate $(28 \mathrm{~kg} \mathrm{P} / \mathrm{ha}$ ) at sowing, but no maintenance fertilizer was applied to 2 - or 3-year-old swards.

To test the ability of sown legumes to compete with companion grasses, plots were oversown with $6 \mathrm{~kg} /$ ha of Brownseed grass (Paspalum pilcatulum Michx.) cv. Rodd's Bay at the 1982 sowing. Brownseed grass was chosen because experience in the dry tropics

Table 2. Chemical analyses for sandy and red loam soils at Gaopoling Farm, Hainan Island.

\begin{tabular}{|c|c|c|c|c|c|c|c|c|c|c|c|c|c|c|c|c|c|}
\hline \multirow{2}{*}{$\begin{array}{l}\text { Depth } \\
\text { (cm) }\end{array}$} & \multicolumn{2}{|c|}{ pH } & \multirow{2}{*}{$\begin{array}{l}\text { Organic } \\
\text { matter }\end{array}$} & \multirow{2}{*}{$\begin{array}{c}\text { Total } \mathbf{N} \\
\mathbf{N}\end{array}$} & \multicolumn{5}{|c|}{ Exchangeable cations } & \multirow{2}{*}{$\begin{array}{c}\text { Available } \\
\text { P }\end{array}$} & \multicolumn{7}{|c|}{ Available trace elements } \\
\hline & $\mathrm{H}_{2} \mathrm{O}$ & $\mathrm{KCl}$ & & & $\mathrm{Ca}$ & $\mathbf{M g}$ & $\mathbf{K}$ & $\mathbf{N a}$ & $\mathrm{Al}$ & & $\mathrm{Cu}$ & $\mathrm{Zn}$ & $\mathrm{Fe}$ & Mn & Mo & $\mathbf{B}$ & Co \\
\hline & & & $(\%)$ & $(\%)$ & & $--(m$ & $q / 100$ & g) -- & & $(\mathrm{mg} / \mathrm{kg})$ & $\cdots$ & -5 & 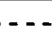 & $\mathrm{ng} / \mathrm{k}$ & $-\ldots$ & $-\ldots$ & $\ldots$ \\
\hline \multicolumn{18}{|c|}{ Deep sandy soil } \\
\hline $0-10$ & 5.8 & 5.4 & 0.63 & 0.04 & 1.78 & 0.58 & 0.20 & 0.63 & nal & 3 & 0.1 & 1.1 & 1.8 & 68 & $<0.1$ & na & na \\
\hline $10-20$ & 5.7 & 5.4 & 0.46 & 0.03 & 1.65 & 0.55 & 0.16 & 0.03 & na & 2 & 0.2 & 0.5 & 16 & 56 & na & na & na \\
\hline $20-40$ & 5.9 & 5.5 & 0.20 & na & 0.72 & 0.31 & 0.05 & na & na & 3 & & & & & & & \\
\hline$>40$ & 6.1 & 5.5 & 0.09 & na & 0.90 & 0.32 & 0.05 & na & na & 6 & & & & & & & \\
\hline \multicolumn{18}{|c|}{ Red loam soil } \\
\hline $0-10$ & 5.8 & 5.4 & 1.36 & 0.09 & 7.58 & 2.55 & 0.42 & 0.07 & na & 25 & 0.3 & 1.2 & 32 & 136 & $<0.1$ & 0.2 & 0.4 \\
\hline $10-20$ & 6.1 & 5.6 & 1.01 & 0.08 & 6.43 & 2.54 & 0.31 & 0.06 & na & 8 & 0.4 & 1.4 & 29 & 66 & na & na & na \\
\hline $20-40$ & 6.3 & 5.6 & 0.34 & na & 1.64 & 1.35 & 0.12 & na & na & na & & & & & & & \\
\hline$>40$ & 6.4 & 5.6 & 0.15 & na & 2.07 & 1.94 & 0.14 & na & na & na & & & & & & & \\
\hline
\end{tabular}

${ }^{\mathrm{I}} \mathrm{na}=$ data not available 
Table 3. Name, sowing rate, germination percentage, and first year establishment of tropical legumes tested at Gaopoling Farm, $1981-1983$.

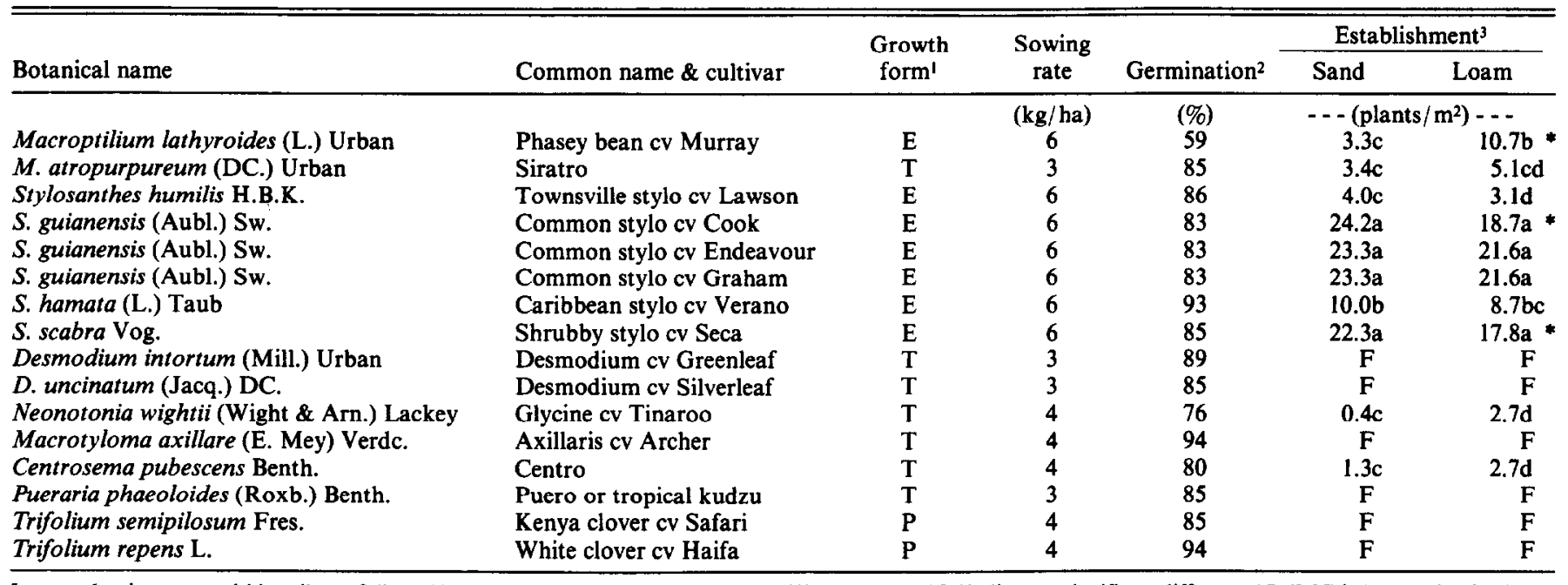

Legume density means within soil type followed by the same letter are not significantly different at $P<0.05$; $*$ indicates a significant difference ( $P<0.05$ ) in legume density due to soil type; ${ }^{1}$ Growth form code: $E=$ erect; $T=$ trailing; $P=$ prostrate; ${ }^{2}$ Germination of seed scarified with hot water treatment; ${ }^{3}$ Establishment for legumes averaged over the 3 sequential sowings (1981, 1982, 1983); F = failed to establish.

of northern Australia had indicated that if left ungrazed this grass will produce a dense stand which was too competitive for legumes (Anning 1982a).

To estimate establishment and persistence, legume plants were counted in two $0.5-\mathrm{m}^{2}$ quadrats/plot at the end of the wet (November) and dry seasons (May/June) of each establishment year. Pasture production was estimated by harvesting forage from four $0.25-\mathrm{m}^{2}$ quadrats at a height of approximately $2 \mathrm{~cm}$ above the ground surface using hand shears. Estimates were made at the end of the wet and dry seasons each year. Harvested material was weighed in the field and subsamples taken to determine botanical composition by hand sorting and dried at $100^{\circ} \mathrm{C}$ for 24 hours to determine dry matter content of sown legumes, grasses, and forbs. All yields are expressed in metric tonnes $(t) /$ ha.

At the end of the dry season each year, plots were grazed with cattle to remove carry-over production from the previous wet season to a level of about $500 \mathrm{~kg} / \mathrm{ha}$. Although legumes remained green for at least part of the dry season, little additional growth was measured during this period and so legumes were evaluated on their wet season performance only.

\section{Statistical Analyses}

Analyses of variance split in time were set up in the Genstat program (Payne et al. 1988) to analyze density and production data from the randomized block design for establishment year performance of legumes in the 3 sequential sowings with soil types (2), establishment years (3), and species (7) as main effects. Least significant differences based on error terms from the appropriate stratum of the analyses of variance for pasture parameters were used to differentiate between significant and nonsignificant means.

Similar analyses were used to test significance of legume and grass production in 1- (mean of sequential sowings in 1981, 1982, and 1983); 2-(mean of 1981 sowing cut in 1982 and 1982 sowing cut in 1983); and 3-(1981 sowing cut in 1983) year-old pasture swards. A linear regression model with fitted terms for year, soil type, pasture age, species, and all significant $(P<0.05)$ second- and third-order interactions was used to predict yield of sward components and verify analyses of variance. The high degree of variability in legume $\left(R^{2}=0.97\right)$, native grass $\left(R^{2}=0.90\right)$, and total $\left(R^{2}=0.88\right)$ yields explained by these models implied that there was no confounding between sites and years within soil types due to pooling data for the analysis of variance.
Linear and nonlinear regressions were used to examine relationships between sown legume performance, rainfall, plant density, and age of pasture.

\section{A. Establishment Year}

\section{Results}

\section{Plant Density}

Only 10 legumes established successfully with mean density $>1$ plants $/ \mathrm{m}^{2}$ on one or both soils (Table 3 ). Perennial stylos ( $S$. guianensis and $S$. scabra) had the highest density, especially on sandy soil except for the cultivar Graham, which established better on loam soil (Table 3). Density of $S$. hamata, an annual/perennial stylo, was half that of the other perennial ecotypes, while establishment of the annual $S$. humilis was only half that of $S$. hamata (Table 3).

In contrast to stylos, legumes with a trailing growth form (siratro, glycine and centro) established better on fertile loam soil (Table 3). Siratro established better than glycine or centro, but was not as dense as swards of $M$. lathyroides. Year of sowing affected $(P<0.01)$ perennial stylo density with more plants establishing in 1981 than in 1982 and 1983. Density of $S$. humilis, S. hamata, and the trailing legumes was not affected by year of establishment even though the growth season was longer and wetter in 1982 and 1983 (Fig. 2; Table 5).

Density of brownseed grass $\left(11\right.$ plants $\left./ \mathrm{m}^{2}\right)$ sown with legumes in the 1982 sowing did not impact significantly on legume establishment.

\section{Production}

Soil type affected $(P<0.01)$ establishment year legume production (Table 5). Legume yield on the loam soil exceeded yield on sand soil by 3 or more times, depending on species (Fig. 2; Table 5). Cook stylo was the most productive legume on loam soil, followed by Endeavour stylo, with Graham stylo and Siratro equal third (1.3 $t /$ ha). On sandy soil there was little difference between legumes in establishment year production (Fig. 3).

Year of establishment did not affect legume production on sandy soil, but did impact on legume yield in newly sown pastures on loam soil (Fig. 2): Cook and Verano yielded significantly more when sown in 1982, Graham and Siratro produced highest yield in the 1981 sowing, while Endeavour and Seca performed well in both 1981 and 1982. Except for Graham, production measured for the 

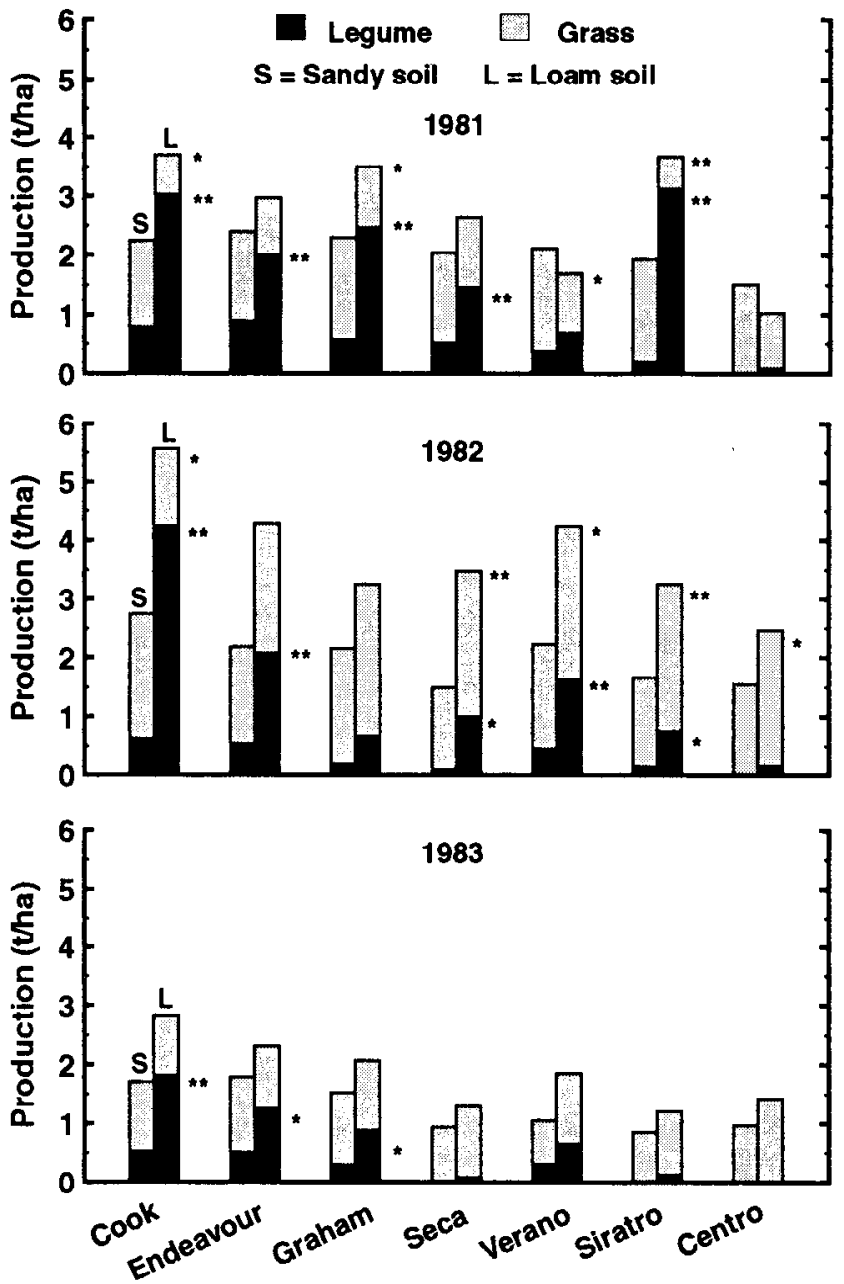

* and ** indicates significant differences in legume or grass yield due to soil type at $P<0.05$ and $P 0.01$

Fig. 2. Establishment year production (t DM/ha) for tropical legumes sown on sand and loam soils at Gaopoling Farm.

Table 4. Legume density (plants $/ \mathrm{m}^{2}$ ) at the end of the wet and dry season for sand and loam at Gaopoling Farm, 1981-1982.

\begin{tabular}{|c|c|c|c|c|}
\hline \multirow[b]{3}{*}{ Legume name } & \multicolumn{4}{|c|}{ Soil type } \\
\hline & \multicolumn{2}{|c|}{ Sand } & \multicolumn{2}{|c|}{ Loam } \\
\hline & Wet $^{1}$ & Dry & Wet & Dry \\
\hline & \multicolumn{4}{|c|}{$\cdots \cdots$} \\
\hline Common stylo $\mathrm{cv}$ Cook & $29.5 \mathrm{a}$ & $24.0 \mathrm{c} *$ & $21.5 \mathrm{bc}$ & $19.8 \mathrm{~b}$ \\
\hline Common stylo cv Endeavour & $26.0 \mathrm{a}$ & $29.3 \mathrm{ab}$ & $20.0 \mathrm{~b}$ & $18.2 b *$ \\
\hline Common stylor cv Graham & $16.8 \mathrm{~b}$ & $27.0 \mathrm{bc} *$ & $30.3 \mathrm{a}$ & $30.0 \mathrm{a}$ \\
\hline Shrubby stylo cv Seca & $26.0 \mathrm{a}$ & $34.2 \mathrm{a} *$ & $18.7 \mathrm{c}$ & $23.0 \mathrm{~b}$ \\
\hline Caribbean stylo cv Verano & $12.3 \mathrm{~b}$ & $8.3 \mathrm{~d}$ & $9.2 \mathrm{de}$ & $7.2 \mathrm{c}$ \\
\hline Townsville stylo cv Lawson & $4.0 \mathrm{c}$ & $0 \mathrm{e}^{*}$ & $4.7 \mathrm{ef}$ & $0.2 \mathrm{~d} *$ \\
\hline Siratro & $4.2 \mathrm{c}$ & $3.2 \mathrm{e}$ & $5.5 \mathrm{ef}$ & $7.2 \mathrm{c}$ \\
\hline Phasey bean cv Murray & $1.3 \mathrm{c}$ & $0 \mathrm{e}$ & $12.2 \mathrm{~d}$ & $0.2 \mathrm{~d} *$ \\
\hline Glycine cv Tinaroo & $0.3 \mathrm{c}$ & $0 \mathrm{e}$ & $3.3 \mathrm{f}$ & $0.2 \mathrm{~d}$ \\
\hline Centro & $1.7 \mathrm{c}$ & $0.2 \mathrm{e}$ & $3.8 \mathrm{f}$ & $2.5 \mathrm{~d}$ \\
\hline
\end{tabular}

Legume density means followed by the same letter are not significantly different at $P<0.05$ within seasons: ${ }^{*}$ indicates a significant difference $(P<0.05)$ in legume density within soil types due to season; ${ }^{1}$ Density for sown legume measured at end of wet season and end of dry season averaged over to years (1981 \& 1982).
Table 5. Significant main effects for establishment year production (tDM/ha) for 3 sequential sowings of tropical legumes sown on sand and loam soils at Gaopoling Farm.

\begin{tabular}{llll}
\hline \hline \multirow{2}{*}{ Main effect } & & \multicolumn{2}{c}{ Parameter } \\
\cline { 3 - 4 } Soil type & Comparison & Legume & Grass \\
& Sand & $0.34 \mathrm{~b}$ & $1.45 \mathrm{a}$ \\
Year & Loam & $1.35 \mathrm{a}$ & $1.46 \mathrm{a}$ \\
& 1981 & $1.16 \mathrm{a}$ & $1.25 \mathrm{~b}$ \\
Sown legume & 1982 & $0.90 \mathrm{~b}$ & $2.00 \mathrm{a}$ \\
& 1983 & $0.47 \mathrm{c}$ & $1.10 \mathrm{~b}$ \\
& Cook & $1.84 \mathrm{a}$ & $1.29 \mathrm{a}$ \\
& Endeavour & $1.22 \mathrm{~b}$ & $1.44 \mathrm{a}$ \\
& Graham & $0.85 \mathrm{c}$ & $1.62 \mathrm{a}$ \\
& Seca & $0.53 \mathrm{~d}$ & $1.46 \mathrm{a}$ \\
& Verano & $0.69 \mathrm{~d}$ & $1.52 \mathrm{a}$ \\
& Siratro & $0.74 \mathrm{~cd}$ & $1.38 \mathrm{a}$ \\
& Centro & $0.05 \mathrm{e}$ & $1.45 \mathrm{a}$ \\
\hline
\end{tabular}

Main cffect means within parameters followed by the same letter are not significantly different at $P<0.05$.

\begin{tabular}{lccc}
\hline \multicolumn{4}{c}{ Sowing to harvest } \\
\hline \hline & 1981 & 1982 & 1983 \\
\hline Growth period (days) & 130 & 172 & 159 \\
Rainfall (mm) & 458 & 879 & 1022 \\
\hline
\end{tabular}

1983 sowing was lowest for all legumes (Fig. 2; Table 5).

Year of establishment had no effect on yield per plant on sandy soil, but reduced $(P<0.05)$ plant size on loam soil with smaller plants present in 1983 compared with 1981 and 1982. Yield per plant of siratro, for example, declined from $47 \mathrm{~g} /$ plant for 1981-2 to $4 \mathrm{~g}$ / plant for 1983 , while stylo size was reduced from 13 to 7 $\mathrm{g} /$ plant. Excessive leaching of nutrients by $417 \mathrm{~mm}$ of rainfall received 2 weeks after sowing may explain in part poor legume performance in the 1983 sowing (Table 5), and the significant negative correlation between rainfall received during the sowing to harvest period (Table 5) and legume yield on sand $\left(R^{2}=0.99\right)$ and loam $\left(R^{2}=0.76\right)$ soils.

First year legume production was correlated with legume density on sandy $\left(R^{2}>0.77\right)$ and loam soil $\left(R^{2}>0.86\right)$ soils for all legumes except for Cook, Endeavour, and Seca stylos. However, production/plant was significantly higher $(P<0.05)$ on loam soil, with individual plants producing between $32 \%$ and $974 \%$ more than those on sandy soil, depending on species and/or year of establishment.

Siratro produced the largest dry matter yield per plant $(32$ g/plant) averaged over the 3 sowings on loam soil, followed by Cook stylo (23 g/plant), with Verano ( $11 \mathrm{~g} /$ plant) and Endeavour stylo (10 g/plant) equal third. By comparison, production per plant averaged only 3 and $4 \mathrm{~g} /$ plant, respectively, for siratro and the stylos growing on sandy soil. Larger plant size on loam soil was attributed to a combination of higher fertility (Table 2) and superior water-holding capacity of soil.

Grass standing crop in legume swards was similar on both soils and was not affected by legume species (Fig. 2, Table 5). However, year of establishment and its interaction with soil type did impact $(P<0.01)$ grass production. Higher grass yield on loam soil in 1982 was due mainly to production of brownseed grass, which accounted for $72 \%$ of the grass component, while 1981 grass yield on loam was reduced to $57 \%$ of sand soil grass production by high legume yield (Table 4). For sand soil, 1981 and 1982 grass yields were similar (Fig. 2) due to poor production of sown brownseed grass, which contributed only $10 \%$ to grass yield at the 1982 sowing. There was no difference in grass yield between soil types in the 1983 sowing, which was lower $(P<0.05)$ than yield for the 1982 sowing for both 

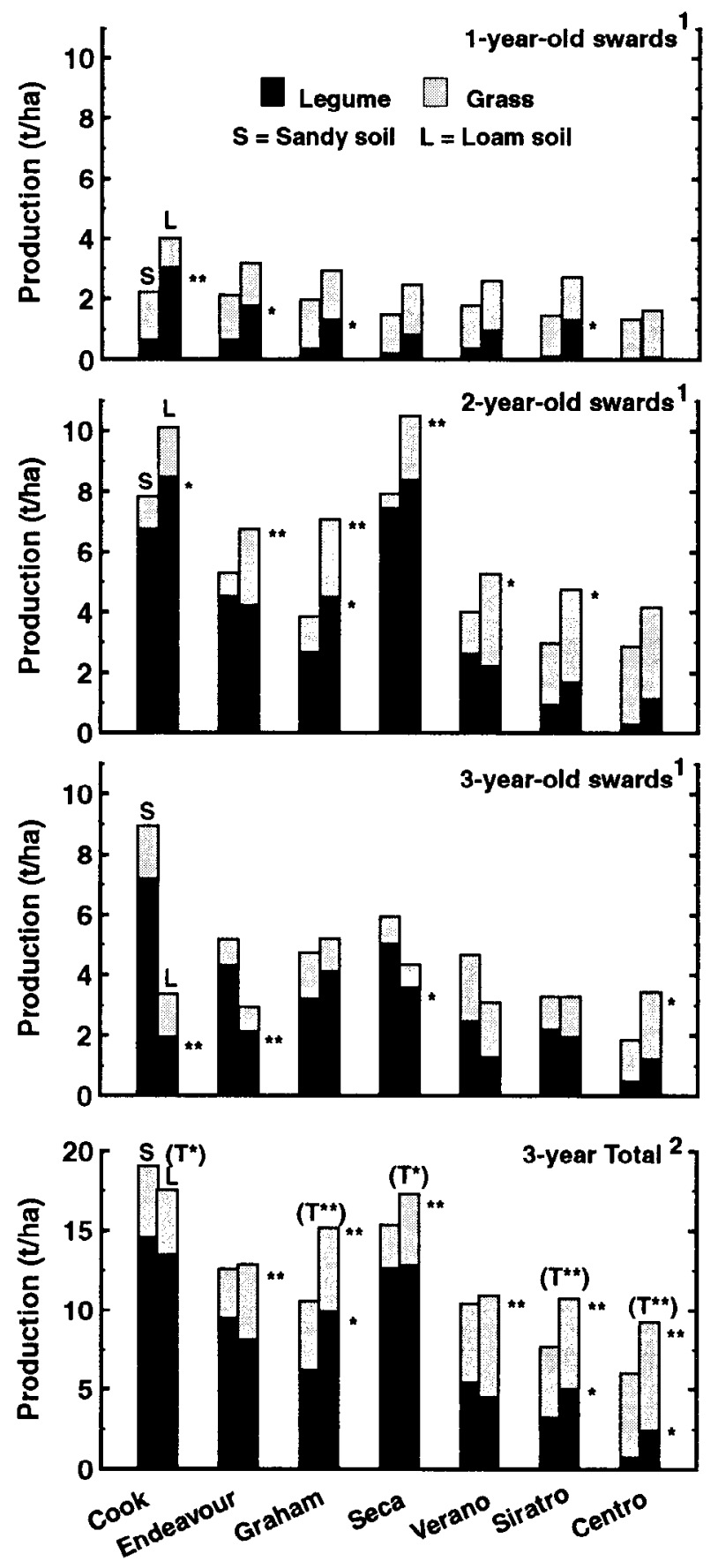

'One-year-old production mean of sequential sowings in 1981,1982, and 1983. Two-year-old production mean of 1981 sowing cut in 1982 and 1982 sowing cut in 1983, and Three-year-old production is 1981 sowing cut in $1983 ; 2$ Total yield $=$ Total sown legume yield + total native $\&$ sown grass; $*$ and ${ }^{* *}$ indicates significant differences in legume or grass yield due to soil type at $P<0.05$ and $P<0.01 ;\left(\mathrm{T}^{*}\right)$ and $\left(\mathrm{T}^{* *}\right)$ indicates significant differences in total yield due to soil type.

Fig. 3. Yield and composition of 1-, 2-, and 3-year-old legume pastures sown on sand and loam soils at Gaopoling Farm (1981-83).

soil types (Fig. 2).

\section{B. Second, Third, and Total Production Iegume Persistence.}

Legume density measured at the end of the first dry season for the 1981 and 1982 sowings showed that phasey bean and Townsville stylo did not survive the 7-month dry season (Table 4) and that
Table 6. Significant main effects for yield of 1-, 2-, and 3-year-old pastures sown on sand and loam soil at Gaopoling Farm (1981-83).

\begin{tabular}{llcc}
\hline & & \multicolumn{2}{c}{ Parameter } \\
\cline { 3 - 4 } & & Legume & Grass \\
\hline Year & One-year-old & 0.84 & $1.45 \mathrm{~b}$ \\
& Two-year old & $3.99 \mathrm{a}$ & $1.96 \mathrm{a}$ \\
& Three-year old & $2.94 \mathrm{~b}$ & $1.37 \mathrm{~b}$ \\
Sown legume & Cook & $4.68 \mathrm{a}$ & $1.42 \mathrm{cde}$ \\
& Endeavour & $2.94 \mathrm{~b}$ & $1.31 \mathrm{de}$ \\
& Graham & $2.70 \mathrm{~b}$ & $1.59 \mathrm{bcd}$ \\
& Seca & $4.25 \mathrm{a}$ & $1.2 \mathrm{e}$ \\
& Verano & $1.66 \mathrm{c}$ & $1.91 \mathrm{ab}$ \\
& Siratro & $1.37 \mathrm{c}$ & $1.71 \mathrm{abc}$ \\
& Centro & $0.54 \mathrm{~d}$ & $2.01 \mathrm{a}$ \\
\hline
\end{tabular}

Main effect means within parameters followed by the same letter are not significantly different at $P<0.05$.

sward regeneration of these legumes depended on the level of seed set at the end of the previous wet season.

Glycine did not survive the dry season (Table 4) and failed to produce sufficient seed for regeneration. On sandy soil, centro also suffered high plant mortality during the dry season (Table 4), but the small nucleus of surviving plants together with annual seedling recruitment resulted in a $0.5-\mathrm{t} /$ ha contribution of centro in 3-yearold pastures (Fig. 3). The higher water-holding capacity of loam soil benefited centro, with $66 \%$ of first-year plants surviving into the second year (Table 4).

\section{Grass and Legume Production}

Cook and Seca stylos were the most productive legumes (Fig. 3; Table 6). Verano stylo and siratro yielded less than the other stylos but out-performed centro (Fig. 3; Table 6). Age of pasture affected $(P<0.05)$ stylo production with yield for 2-and 3-year-old swards exceeding 1-year-old pastures by up to 7.5 $\mathrm{t} /$ ha/year, depending on species and soil type (Fig. 3). Although production was higher for 1-year-old swards on loam soil, soil type had no overall effect on yield except for Graham stylo, which performed better on loam soil (Fig. 3).

The full effect of soil type on legume performance was masked by a wildfire which burned the 1981 loam site in late August, 1983, and significantly reduced yield of 3-year-old legume swards (Fig. 3). Production loss due to fire, predicted from logarithmic equations fitted to production data for 1-year-old and 2-year-old swards on loam soil, ranged from $1.3 \mathrm{t} /$ ha for Graham stylo to 7 $\mathrm{t} /$ ha for Cook stylo. Better post-fire recovery was observed with Graham and Seca stylos, which produced higher $(P<0.05)$ yields as 3 year-old swards than other legumes on loam soil (Fig. 3). Production of centro and siratro was least affected by pasture age and fire (Fig. 3).

On sandy soil, production patterns of time for stylos were logarithmic (Year $1<$ Year 2 = Year 3), except for S. scabra which produced significantly more dry matter in 2- than 3-year-oldpastures. Centro yield was low and unaffected by time, but siratro yield increased $(P<0.05)$ with time and produced yield equivalent to Verano stylo as 3-year-old sward (Fig. 3).

There were differences $(P<0.05)$ in companion grass production associated with interactions between age of pasture, sown legume, and soil type. While there was no difference in companion grass yield between sandy and loam soils in 1- and 3-year-old legume swards, grass production on loam soil in 2-year-old stands was double that of sandy soil (2.5 vs $1.3 \mathrm{t} / \mathrm{ha}-\mathrm{Fig}$. 3 ). This was due to superior performance in 2-year-old plots on loam soil of brownseed grass $(1.8 \mathrm{t} / \mathrm{ha})$ sown with legumes in 1982 .

On both soil types, Verano stylo and centro were least competitive with companion grass production exceeding $2 \mathrm{t} /$ ha in 3-ycarold legume swards, whereas Endeavour and Seca stylos reduced 
grass yield to $<0.9 \mathrm{t} /$ ha by the third production year (Fig. 3).

\section{Total Sward Production}

Total production was highest in Cook and Seca swards and lowest in siratro and centro plots on both soil types (Fig. 3). Due to superior yield of legumes in establishment year, accumulated production on loam soil for 1-and 2-year-old stands exceeded accumulated production on sand soil by $34 \%$ to $70 \%$, depending on legume sown, but overall there was no difference between soil types in total pasture yield accumulated over 3 production years $(11.7 \mathrm{vs}$ $13.4 \mathrm{t} / \mathrm{ha} / 3-\mathrm{yr}$ ) duc to the effects of the wildfire on loam soil in 1983.

On sandy soil, total production of perennial stylo-based pasture exceeded $4.0 \mathrm{t} /$ ha in 2- and 3-year-old swards, which is about 4 times the production expected from unimproved sandy rangeland. The tall growing stylos (1-2 m) cultivars, Cook, Endeavour, and Seca accounted for $75 \%$ or more of total production, whereas the shorter stylos $(<1 \mathrm{~m})$, Graham and Verano, made up less than $70 \%$ of total production. Total production of siratro and centro were lower $(P<0.05)$ than that of the stylos due to the small contribution of these trailing legumes to production in 1-and 2-year-old swards (Fig. 3).

For loam soil, yield of 2-year-old pastures exceeded unimproved rangeland by at least $2 \mathrm{t} / \mathrm{ha}$ and as much as $8 \mathrm{t} / \mathrm{ha}$ for swards of Cook and Seca stylo. Although the effects of the wildfire preclude comparisons for 3-year-old swards, prediction equations based on sand soil response pattern to age of pasture suggest that total production of perennial stylo-based pasture for 3-year-old swards on loam soil should exceed $8 \mathrm{t} /$ ha and $5 \mathrm{t} /$ ha for siratro-based pastures.

\section{Discussion and Management Implications}

Stylosanthes performed better than other genera on the 2 soil types, indicating the value of this genus for range improvement in south China. Of the stylos tested, the common stylo cultivars Cook, Endeavour, and Graham established better than Caribbean (Verano) and shrubby (Seca) stylos. The common stylos and siratro more than doubled the annual forage production expected from fertilized unimproved rangelands on both soil types (Michalk and $\mathrm{Fu}$ 1988).

Cook, a mid-season flowering type, was the highest yielding legume on both soil types even though the $1,001-\mathrm{mm}$ annual rainfall in Dong Fang County is marginal for this cultivar (Cameron 1985). However, observations made on commercial pastures in Australia and China indicate that the performance of Cook stylo under grazing declines markedly with time and many disappear after several years. Mclvor et al. (1979) found this decline to be most pronounced in 3-year-old swards after good growth in previous years. In contrast, Graham is more persistent under conditions of drought and heavy grazing, and is the common stylo recommended for range improvement on moderately fertile loam soils in the lower rainfall regions of south China in combination with siratro.

Low phosphorus requirements of Verano and Seca (McIvor 1984) enabled mixtures of these stylo cultivars to dominate swards on low P sandy soils, even without application of superphosphate (Michalk and Fu 1988). While carrying capacity may increase due to extra dry matter produced, livestock production may be limited by the low level of phosphorus in unfertilized Seca and Verano forage. Both species respond significantly to superphosphate applied to sandy soil (Michalk and Fu 1988, D.L. Michalk, unpublished data).

Mixtures of Verano and Seca are recommended for improvement of Hainan's sandy soil rangeland because Seca is relatively low yielding in its establishment year due to slower radicle elonga- tion and seedling growth rate (Gardener 1978) and maintains a small seed pool with little seed surviving in the soil for more than 2 years (Mott 1982), whereas Verano establishes quickly and flowers continually throughout its vegetative growth phase to produce large seed reserves. This enables Verano to persist for long periods of time even when managerial extremes and grazing abuse prevent an annual seed increment (Gardener 1981).

When sown together, Verano is initially the dominant legume, but is overtaken by Seca after 2 or 3 years. However, Verano still maintains its well-disturbed seed pool from which it colonizes any site in the community left vacant by other plants (Gardener 1981). This provides a buffer against the need to change management policy such as a reduction in grazing pressure that would otherwise be required to aid re-establishment of Seca in a situation where large numbers of mature plants were lost through fire or disease (Mott 1982).

Townsville stylo, an annual which persists in dry climates by seed survival rather than plant survival, did not persist or produce acceptable yield in this evaluation. This may have been due to its intolerance of shading, and failure to keep companion grasses in check did not enable Townsville stylo to compete for light particularly in the seedling stage. Wet season grazing may improve establishment and production of Townsville stylo, but as an anthracnosesusceptible annual it is not likely to be used in preference to anthracnose-tolerant perennial stylos for range improvement in south China.

Siratro was the only nonstylo to produce moderate $(2 t / \mathrm{ha})$ yield and show relative stability with sward age, especially on the more fertile loam soil. Superior drought tolerance enabled siratro plants to pass through the dry season without significant loss. With regular fertilization and controlled grazing, large area sowings on this soil type at Gaopoling Farm are still highly productive after 8 years with siratro still contributing $40 \%$ dry matter in siratroSetaria sphacelata (Schum) Stapf ex Massey swards (Zhu ChinMing, unpublished data). However, siratro has not persisted in other sowings in south China due to heavy wet season grazing (or cutting), and failure to fertilize regularly with superphosphate.

Siratro can re-populate regularly from soil seed reserves (Jones and Jones 1977) provided pastures are initially stocked lightly to allow seed reserves to accumulate. At Gaopoling Farm, large paddocks of siratro remain vigorous and productive because cattle were excluded from newly June/July sown siratro-based pastures until October and then grazed at 0.6 to $1 \mathrm{AU} /$ ha until December to utilize $50 \%$ or less of available forage (Michalk and Dunn 1984).

Although not as productive as siratro, centro persisted on both soil types, and further testing is warranted on more drought hardy species. These include $C$. acutifolium Benth., a Colombian selection, which is sown with gama grass (Andropogon gayanus Kunth.) on infertile sandy soils in South America (CIAT 1987), and $C$. brasilianum Benth., which persists under grazing in dry tropical Australia (Anning 1982b).

Archer axillaris failed to establish on either soil type at Gaopoling Farm. However, it has performed well in wetter locations (annual rainfall 1,200 mm) in south China, and was one of the most successful legumes tested at the Qian Jiang Model Farm in Guangxi Province (Liu Ke-Wen, pers. comms.). In northern Australia, axillaris has shown long-term persistence and vigour under grazing on fertile soils but does not persist or effectively nodulate on sandy sites (Anning 1982b).

In addition to yield, grass-legume compatability is an important aspect of legume evaluation. Legume content and animal performance are closely related with liveweight gains in cattle decreasing when legume content falls below $40 \%$ (Bryan and Evans 1973). Contribution of all perennial stylos and siratro in 3-year-old swards with volunteer companion grasses exceeded this threshold 
on both soil types at Gaopoling Farm in evaluation plots and in commercial sowings. When sown with brownseed grass, Verano was the only stylo unable to compete with this aggressive grass and legume content declined to $22 \%$ on sandy soil and $11 \%$ on loam soil in 2-year-old swards. Compatibility of stylos and siratro with other grasses tested in western Hainan is reported by Michalk et al. 1993.

The wildfire which occurred on loam soil in 1983 confirmed the fire-resistant/drought-tolerance relationship reported by Gardener (1980) for stylos. As expected, Cook and Endeavour stylos, which are better adapted to wetter areas than Dong Fang County showed less resistance to fire in terms of post-fire dry matter production than the more drought-tolerant stylos. Fire resistance of Seca and Graham stylos is an important attribute as it allows rangelands oversown with these legumes to remain ungrazed with greater safety until required by cattle late in the dry season.

Fire resistance could also provide a useful management tool for pastures sown with Seca stylo as burning appears to be the easiest and cheapest method of removing aged woody growth and providing rejuvenated herbage of higher quality (Gardener 1980); however, a reduction in stocking rate may be needed to ensure regeneration of a productive sward (Mott 1982), especially when shrubby stylo is sown with Caribbean stylo as a companion. As is the case in northern Australia, fire could also play an important part in renovating Verano-based pastures which have a dense stand of native grass suppressing stylo germination (Mott 1982).

No incidence of anthracnose was observed in this legume study, but the fungus has attacked stylos swards at the Tropical Plant Research Institute in Danxian County (Hainan), and was reported in Guangxi Province in 1983 (Hong 1985). These attacks coupled with the known occurrence of more virulent races of Colletotrichum spp. highlights the need to import more germplasm of anthracnose-resistant stylos and other successful legume genera for testing in China.

Other genera which warrant testing include Alysicarpus, Atylosia, Clitoria, Desmodium, Macrotyloma, Rhynchosia and Vigna (Anning 1982b; Williams and Clements 1985). Some of these genera are endemic to southern China (Groff et al. 1923, 1924, 1925; Merrill 1927; Merrill 1928, 1930, 1932, 1934) and collections made in 1980 (Hwang et al. 1986) and 1984 (Schultze-Kraft et al. 1984) identified 14 potential forage legumes from which Alsicarpus vaginalis (L.) DC var. diversifolius Wall., Desmodium heterocarpon (L.) DC, and Dendrolobium lanceolatum (Dunn) Schindler (ex. Desmodium dunii) were selected for further evaluation by the Animal Husbandry Research Institute of Guangdong (Hwang et al. 1986).

Although further introduction and evaluation is needed to select forage legumes for other regions (e.g., rangelands with acid infertile soil) and to minimize disease incidence in stylos, assessment of fertilizer requirements, formulation of grazing strategies, development of seed production systems, and improvement of technical extension services are also needed to ensure long-term stability and profitability of legume-improved rangelands in south China. However, there is a dearth of trained personnel in these research areas and exchanges with advanced countries and training of Chinese scientists and technicians are also urgently needed (Hong 1985).

\section{Literature Cited}

Anning, P. 1982a. Evaluation of introduced grass species for pastures in the dry tropics of north Queensland. Trop. Grassl. 16:40-49.

Anning, P. 1982b. Evaluation of introduced legume species for pastures in the dry tropics of north Queensland. Trop. Grassl. 16:146-155.

Anonymous. 1982. Hainan Island mining and minerals survey mission. Aust. Gov. Pub. Ser. Canberra.

Ayres, J.F., D.L. Michalk, and S.E. Dunn. 1983. Model cattle farm in China. p. 19. In: 1983 Annu. Rep. NSW Dep. Agr., Wollongbar Agr. Inst.
Bishop, H.G., J.M. Hopkinson, and C.D. Webb. 1981. Graham stylo...more than a replacement for Schofield. Queensl. Agr. J. 107:21-25. Bryan, W.W., and T.R. Evans. 1973. Effect of soils, fertilizers and stocking rates on pastures and beef production on the Wallum of south-eastern Queensland. 2. Liveweight change and beef production. Aust. J. Exp. Agr. Anim. Husb. 13:530-536.

Cameron, D.G. 1985. Tropical and subtropical pasture legumes: 7. Common stylo (Stylosanthes guianensis var. guianensis): the original wet tropical coastal pioneer legume. Queensl. Agr. J. 111:151-156.

CIAT International. 1987. Highlights: tropical pastures program. CIAT International 6:4-5 and 16.

Gardener, C.J. 1978. Seedling growth characteristics of Stylosanthes. Aust. J. Agr. Res. 29:803-813.

Gardener, C.J. 1980. Tolerance of perennating Stylosanthes plants to fire. Aust. J. Exp. Agr. Anim. Husb. 20:587-593.

Gardener, C.J. 1981. Population dynamics and stability of Stylosanthes hamata cv. Verano in grazed pastures. Aust. J. Agr. Res. 32:63-74.

Gillard, P., L.A. Edye, and R.L. Hall. 1980. Comparison of Stylosanthes humilis with $S$. hamata and $S$. subsericea in the Queensland dry tropics: Effects on pasture composition and cattle liveweight gain. Aust. J. Agr. Res. 31:205-220.

Groff, G.W., E. Ding, and E.H. Groff. 1923. An enumeration of the McClure collection of Hainan Island. Lingnan Agr. Rev. 1:27-86.

Groff, G.W., E. Ding, and E.H. Groff. 1924. An enumeration of the McClure collection of Hainan Island. Lingnan Agr. Rev. 2:9-43.

Groff, G.W., E. Ding, and E.H. Groff. 1925. An enumeration of the McClure collection of Hainan Island. Lingnan Agr. Rev. 3:18-34.

Hong, Fu-Zeng. 1985. Studies on the tropical and subtropical pasture resources and their exploitation prospects in China. Trop. Agr. Res. 18:1-8.

Humphreys, L.R. 1967. Townsville lucerne-history and prospect. J. Aust. Inst. Agr. Sci. 33:3-13.

Hutton, E.M. 1970. Tropical pastures. Adv. Agron. 22:1-73.

Hutton, E.M. 1979. Problems and successes of legume-grass pastures, especially in tropical Latin-America, p. 81-93. In: A.P. Sanchez and L.E. Tergas (eds.), Pasture production in acid soils of the tropics. CIAT, Cali, Columbia.

Hwang, Miao-Yang, Wun Lan-Xiang, and Zhang Ching-Zhe. 1986. The main varieties of forages and their evaluation in southern China, $p$. 76-79. In: G.J. Blair, D.A. Ivory and T.R. Evans (eds.) Forages in southeast Asian and South Pacific agriculture. ACIAR Proc. Series 12, Canberra, Australia, p. 76-79.

Irwin, J.A., and D.F. Cameron. 1978. Two diseases in Stylosanthes spp. caused by Colletotrichum gloeosporioides in Australia, and pathogenic specialization within one of the causal organisms. Aust. J. Agr. Res. 29:305-317.

Jones, R.J., and R.M. Jones. 1977. The ecology of Siratro-based pastures, p. 353-367. In: J.R. Wilson (ed.), Plant relations in pastures. CSIRO, Melbourne, Australia.

Kretschmer, A.E. 1965. Stylosanthes humilis, a summer growing, selfregenerating, annual legume for use in Florida permanent pastures. Proc. Soil \& Crop Soc. Fla. 25:248-262.

McIvor, J. 184. Phosphorus requirements and responses of tropical pasture species: native and introduced grasses, and introduced legumes. Aust. J. Exp. Agr. Anim. Husb. 24:370-378.

Mellvor, J.G., H.G. Bishop, B. Walker, and M.T. Rutherford. 1979. The performance of Stylosanthes guianensis accessions at two sites in coastal north and central Queensland. Trop. Grassl. 13:38-44.

't Mannetje, L. 1974. Relations between pasture attributes and liveweight gains on a subtropical pasture, 3:386-390. In: Grassland Utilization 1. Proc. XII Internat. Grassl. Congr. Moscow, USSR.

Merrill, E.D. 1927. An enumeration of Hainan plants. Lingnan Sci. J. 5:1-186.

Merrill, E.D. 1928. A supplementary list of Hainan plants. Lingnan Sci. J. 6:171-283, 323-332.

Merrill, E.D. 1930. A supplementary list of Hainan plants. Lingnan Sci. J. 9:35-44.

Merrill, E.D. 1932. A supplementary list of Hainan plants. Lingnan Sci. J. 11:37-61.

Merrill, E.D. 1934. A supplementary list of Hainan plants. Lingnan Sci. J. 13:57-73.

Michalk, D.L. 1986. Hainan Island: A brief historical sketch. J. HK Branch Royal Asiatic Soc. 26:115-144. 
Michalk, D.L., and S.E. Dunn. 1984. Pasture development and cattle management at Gaopoling Model Cattle Farm: Summary of achievements and recommendations for further development, Final Rep. to Agr. Bur. of Guangdong Province, Overseas Proj. Sec., NSW Agr. \& Fisheries, p. 146.

Michalk, D.L., and Fu Nan-Ping. 1988. Verano stylo: A useful legume for range improvement on the dry tropics of Hainan Island, China, p. 345-349. In: Panjab Singh, Vinod Shankar and A.K. Srivastava (eds.), Proc. 3rd. Int. Rangeland Congr. Range Manage Soc. India, Jhansi, India.

Michalk, D.L., Fun Nan-Ping, and Zhu Chin-Ming. 1993. Improvement of dry tropical rangelands in Hainan Island, China: 2. Evaluation of Australian pasture grasses. J. Range Manage. 46:265-270.

Mott, J.J. 1982. Fire and survival of Stylosanthes spp. in the dry savanna woodlands of the Northern Territory: Aust. J. Agr. Res. 33:203-211

Payne, R.W. and Committee. 1988. Genstat 5 reference Manual. Oxford Univ. Press, Oxford, England.

Saville, D.G., and K.P. Sheridan. 1980. Guangdong:New South Wales' sister province in China. Agr. Gaz. NSW. 91:4-6.
Schultze-Kraft, J., Jiang Hou-Ming, and Huang Xun-Wen. 1984. Tropical forage legumes on Hainan Island, China. Plant Genetic Resources Newsletter 59, IBPGR-FAO, Rome, Italy, p. 1-3.

Walker, J.L. 1983. Introduction, p.3-4. In: R.L. Burt, P.P. Rotar, J.L. Walker and M.W. Silvey (eds.), The role of Centrosema, Desmodium and Stylosanthes in improving tropical pastures, Westview Tropical Agr. Ser., No. 6., Westview Press, Boulder, Colo.

Williams, R.J., and R.J. Clements. 1985. The future role of plant introduction in the development of tropical pastures in Australia, p. 20-28. In: G.J. Murtagh and R.M. Jones (eds.), Proc. 3rd. Aust. Conf. Trop. Past. Trop. Grassld. Soc. Aust., Occas. Pub. 3.

Xiong, Guo-Yan, and Tang Wan-Long. 1986. Discrimination analysis of soil utilization modes in Hainan Island. Acta-Pedologica Sinica 23:69-81 [in Chinese].

Zhao, Zi-Yang. 1981. China's economy and development principles. Foreign Language Press, Beijing, China.

Zhao, Qi-Guo, and Shi Hua. 1986. On the genesis, classification and characteristics of the soils in tropical and subtropical China. p. 197-228. In: C.K. Li et al. (ed.), Proc. Int. Sym. Red Soils, Sci. Press, Beijing, China. 